\title{
The relationship between river basin specific (RBS) pollutants and macroinvertebrate communities
}

\author{
Nataša Popović, ${ }^{1 *}$ Maja Raković,,${ }^{1}$ Jelena Đuknić, ${ }^{1}$ Béla Csányi, ${ }^{2}$ József Szekeres, ${ }^{2}$ Péter Borza, ${ }^{2}$ Jaroslav Slobodnik, ${ }^{3}$ \\ Igor Liška, ${ }^{4}$ Djuradj Milošević, ${ }^{5}$ Stoimir Kolarević, ${ }^{6}$ Vladica Simić, ${ }^{7}$ Bojana Tubić, ${ }^{1}$ Momir Paunović ${ }^{1}$ \\ ${ }^{1}$ University of Belgrade, Institute for Biological Research "Siniša Stanković", National Institute of Republic of Serbia, Bulevar despota \\ Stefana 142, 11060 Belgrade, Serbia; ${ }^{2}$ Hungarian Academy of Sciences (MTA), Centre for Ecological Research, Danube Research \\ Institute, Jávorka Sándor u. 14, 2131 Göd, Hungary; ${ }^{3}$ Environmental Institute, Okružná 784/42, 97241 Koš, Slovak Republic; \\ ${ }^{4}$ International Commission for the Protection of the Danube River, Wagramer Strasse 5, A-1220 Vienna, Austria; ${ }^{5}$ Department of Biology \\ and Ecology, Faculty of Sciences and Mathematics, University of Niš, Višegradska 33, 18000 Niš, Serbia; ${ }^{6}$ University of Belgrade, \\ Faculty of Biology, Studentski trg 3, 11000 Belgrade, Serbia; ${ }^{7}$ Institute of Biology and Ecology, Faculty of Science, University of \\ Kragujevac, Radoja Domanovića 12, 34000 Kragujevac, Serbia
}

\begin{abstract}
This study was carried out to identify the relations between macroinvertebrate communities and river basin specific (RBS) pollutants in the Danube River. The investigation was performed at 68 sites along $2500 \mathrm{~km}$ of the Danube. Forward selection (FS), canonical correspondence analyses (CCA), the Spearman correlation coefficient (SC) and BIO-ENV analysis (to detect synergistic effects) were used to identify the relations between the macroinvertebrate dataset and selected biological metrics with RBS pollutants. Of the 20 analysed pollutants (preselected based on NORMAN network methodology), seven (2,4-dinitrophenol, chloroxuron, bromacil, dimefuron, amoxicillin, bentazon and fluoranthene) were found to significantly correlate with macroinvertebrate communities. BIOENV analysis revealed 3 subsets of environmental variables that were in high correlation with the biota resemblance matrix, consisting mainly of a combination of the above-mentioned pollutants. Our results indicate that there are significant correlations between chemical determinants and aquatic biota. Moreover, this study contributes to the validation of the methodology used for prioritization of RBS pollutants proposed by the NORMAN network.
\end{abstract}

\section{INTRODUCTION}

The structure of macroinvertebrate communities is strongly influenced by many natural and anthropogenic stressors (e.g. hydromorphological and hydrogeological features, the physical and the chemical contaminants of the water and sediment, as well as the substrate type and interactions with other organisms) (Melo, 2009; Milošević et al., 2016; Rico et al., 2016).

Changes in community composition are governed by

Corresponding author: natasa.popovic@ibiss.bg.ac.rs

Key words: Macroinvertebrate; Danube River; river basin-specific pollutants; multiple stressors; synergistic effects.

Edited by: Esteban Balseiro, Universidad Nacional del Comahue, Bariloche, Argentina.

Received: 8 May 2019.

Accepted: 16 November 2019.

This work is licensed under a Creative Commons Attribution NonCommercial 4.0 License (CC BY-NC 4.0).

${ }^{\circ}$ Copyright: the Author(s), 2019

Licensee PAGEPress, Italy

J. Limnol., 2020; 79(1): 59-69

DOI: 10.4081/jlimnol.2019.1915 the adaptability and environmental preferences of each taxon. Sensitive taxa could be used as bioindicators for altered environmental conditions (Melo, 2009; Collier et al., 2013; Milošević et al., 2016). Knowledge of the optimal environmental conditions for survival of certain macroinvertebrate taxa and the ecological amplitude for the individual environmental factors allowed us to include them in assessing the ecological status of lotic systems.

The Danube is a river with the largest drainage area in Europe. The many densely-populated cities along its banks, agricultural activities, transportation and industries exert a profound anthropogenic influence on the morphology, hydrology, chemistry, as well as flora and fauna of the Danube's aquatic habitats (Liška et al., 2008, Kolarevic et al., 2011; Liška et al., 2015).

Bearing in mind the diversity of chemical pollutants and their harmful effects on aquatic biota and human health, but also the limitations in assessing all of them, there is an obvious need to choose specific pollutants for monitoring the river basin (Slobodnik et al., 2015; Slobodnik and von der Ohe, 2015). The updated Directive 2013/39/EU (European Union, 2013) establishes environmental quality standards (EQS) for 45 priority substances, which are expressed as the annual average (AA) concentrations and the maximum allowable concentrations (MACs).

A list of 20 specific pollutants for the Danube River Basin was developed by Slobodnik and von der Ohe (2015). It is based on the NORMAN methodology (von 
der Ohe et al., 2011), and specific pollutants were identified on the ratio of MEC95 (maximum environmental concentration, $95^{\text {th }}$ percentile) to PNEC (predicted no-effect concentration). The purpose of NORMAN activities is to optimize the selection of the most "problematic" pollutants. The use of new substances in massive industrial production with possible harmful effects to the environment is enormous and we have to find a solution to promptly select the important pollutants.

Numerous studies have analysed the physical and chemical environmental parameters that could influence community composition and structure of the aquatic macroinvertebrates (Weatherhead and James, 2001; Navarro-Ortega et al., 2015; Kuzmanović et al., 2016; Milošević et al., 2016; Rico et al., 2016). However, a small number of studies were devoted to the influence of xenobiotic compounds on macroinvertebrates in their natural habitat. Hence, there is a need to address the following issues related to the correlation between RBS pollutants identified as priority and the macroinvertebrate communities of the Danube river, and to detect the subset of RBS pollutants which is the most linkage with a macroinvertebrate community.

\section{METHODS}

\section{Study area}

The Danube River, with a length of $2826 \mathrm{~km}$ and average altitude of $458 \mathrm{~m}$, flows from west to east through 10 countries (Germany, Austria, Slovakia, Hungary, Moldova, Croatia, Serbia, Bulgaria, Romania and Ukraine). A huge number of cities with more than 200 million inhabitants have been built on its banks, thereby altering its hydromorphology and water quality, which has a negative impact on aquatic biota. The Danube River links 14 economically, environmentally and culturally different countries. Agriculture is very important, that supplies cities with food but also discharge pesticides in water. At the same time, the river is the major source of drinking water in all countries (except Bulgaria) (Sommerwerk et al., 2010; Gajić et al., 2015). The Danube River is divided into 10 sectors (S) according to Robert et al. (2003): S1 - Upper Course of the Danube; S2 - Western Alpine Foothills of the Danube; S3 - Eastern Alpine Foothills of the Danube (S 1-3 is considered as upper stretch of the Danube); S4 - Lower Alpine Foothills of the Danube; S5 - Hungarian Danube Bend; S6 Pannonian Plain of the Danube; S7 - Iron Gate (S 4-7 is middle stretch); S8 - Western Pontic Danube; S9 - Eastern Wallachian Danube; S10 - Danube Delta (S 8-10 is considered as lower stretch). Analyses of the community and environmental factors were performed in these sectors.

\section{Sampling}

In the summer of 2013, during the Third Joint Danube Survey (JDS 3), samples were taken from 68 sites along $2500 \mathrm{~km}$ of the Danube River (Fig. 1).

Samples of macroinvertebrates were collected from the left and right banks of the river (a total of 136 samples), using a standard benthological hand net (500$\mu \mathrm{m}$ mesh size, net frame $25 \times 25 \mathrm{~cm}$ ) and applying the kick and sweep technique (K\&S) (Graf et al., 2015a). All available habitats were taken into the consideration during collection of the biological material (multihabitat sampling procedure - MHS). Each sample consisted of twenty sub-samples (pooled together), in order to cover all substrate types and hydraulic conditions. Samples were fixed with $4 \%$ formaldehyde. The biological material was identified to the lowest possible taxonomic level (species in most of the cases) in the laboratory of the Institute for Biological Research "Siniša Stanković", University of Belgrade, and in the Department of Biology and Ecology, Faculty of Sciences and Mathematics, University of Niš, Serbia and in the Centre for Ecological Research, Danube Research Institute, Hungarian Academy of Science.

At the same time, from all sampling sites water and sediment samples for chemical analyses were collected. Water samples for physico-chemical and chemical analyses were taken from the middle of the river. Surface sediment samples from left and right bank were mixed and wet sieved to obtain $63 \mu \mathrm{m}$ fraction. These samples were transported to leading national laboratories in Germany, Austria, Czech Republic, Slovakia, Croatia, Serbia and Italy, where chemical analyses were performed. The details on the study design and sampling methods are presented in Liška et al. (2015).

\section{Statistical analyses}

Statistical data processing was performed using the Flora Software package (Karadžić, 2013). To analyse the heterogeneity of the macroinvertebrate dataset, detrended correspondence analysis (DCA) was employed, while the canonical correspondence analysis (CCA) with singular value decomposition (SVD) algorithm was performed to estimate the correlation between the macroinvertebrate taxa and chemical water parameters (20 RBS pollutants), previously defined by Slobodnik et al. (2015) and by Slobodnik and von der Ohe (2015) (Tab. 1). To identify the most influential chemical variables in the water, the forward selection (FS) method based on Pearson's correlation test $(\mathrm{P}<0.05)$ and the Monte Carlo permutation test ( 999 permutations, $\mathrm{P}<0.05$ ) were used.

In addition, biological environmental gradient (BIOENV) analysis (Clarke and Warwick, 2001) was performed in order to test the relationship between the community and the concentration of chemical pollutants. 
Tab. 1. List of 20 prioritized RBS pollutants for the Danube River according to Slobodnik et al. (2015), with the number of sites where they were detected, the minimum and maximum recorded concentrations and the standard deviation (St. dev).

\begin{tabular}{|c|c|c|c|c|c|}
\hline No. & Substance $(\mu \mathrm{g} / \mathrm{L})$ & No. of sites substance detected & Min & Max & St. dev. \\
\hline 1 & 2,4-Dinitrophenol (DNP) & 68 & 0.01 & 0.04 & 0.007583024 \\
\hline 2 & Perfluorooctansulfonate (PFOS) & 63 & 0.002404459 & 0.02623 & 0.004235189 \\
\hline 3 & Chloroxuron & 65 & 0.0014 & 0.04 & 0.006666883 \\
\hline 4 & Desethylterbutylazine & 54 & 0.0031 & 0.014 & 0.002144425 \\
\hline 5 & 2-hydroxy atrazine & 53 & 0.002 & 0.02 & 0.002711988 \\
\hline 6 & Bromacil & 31 & 0.0231236 & 0.186626 & 0.03574977 \\
\hline 7 & Dimefuron & 58 & 0.0005157 & 0.0412553 & 0.008546081 \\
\hline 8 & Bisphenol A & 30 & 0.0055565 & 1.339275 & 0.309721162 \\
\hline 9 & $\operatorname{Benzo}(g, h, i)$ perylene & 65 & 0.0007 & 0.029 & 0.003856138 \\
\hline 10 & Diazinon & 21 & 0.001 & 0.004 & 0.000815239 \\
\hline 11 & Indeno(1,2,3-c,d)pyrene & 15 & 0.0000034 & 0.0037 & 0.001206503 \\
\hline 12 & Linuron & 32 & 0.0001 & 1.4225 & 0.449419718 \\
\hline 13 & Amoxicillin & 33 & 0.0014602 & 0.1331076 & 0.024708156 \\
\hline 14 & Metazachlor & 30 & 0.0005 & 0.0155 & 0.004063954 \\
\hline 15 & 17beta-estradiol & 8 & 0.0019 & 0.0227 & 0.006775943 \\
\hline 16 & Benzo(a)pyrene & 3 & 0.0024 & 0.0000024 & 0.001356309 \\
\hline 17 & Diclofenac & 51 & 0.000892128 & 0.068804665 & 0.012758548 \\
\hline 18 & Bentazon & 61 & 0.003 & 0.02 & 0.002485741 \\
\hline 19 & Fipronil & 1 & 0.02 & 0.02 & 0 \\
\hline 20 & Fluoranthene & 58 & 0.002 & 0.0204 & 0.002809182 \\
\hline
\end{tabular}

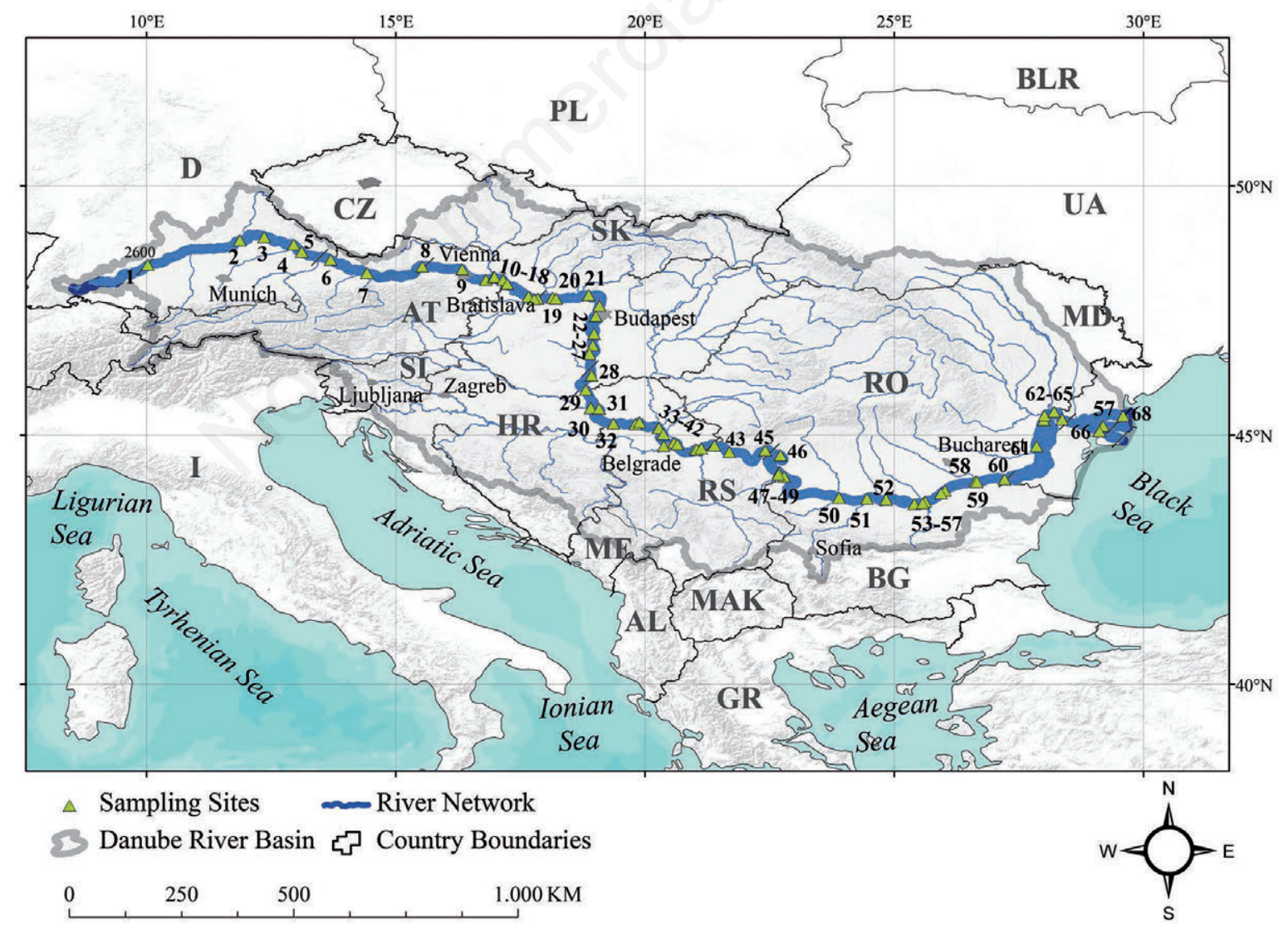

Fig. 1. Localities along the 10 sectors of the Danube River: Sector 1 (S1) - locality 1; Sector 2 (S2) - localities 2-5; Sector 3 (S3) - 6-8; Sector 4 (S4) - 9-18; Sector 5 (S5) - 19-27; Sector 6 (S6) - 28-42; Sector 7 (S7) - 43-45; Sector 8 (S8) - 46-60; Sector 9 (S9) - 61-65; Sector 10 (S10) - 66-68. 
As an input matrix for BIO-ENV analysis (Clarke and Warwick, 2001), a Euclidean distance matrix for 20 RBS pollutants was prepared. Using this matrix, BIO-ENV compares the chemical parameters with community structure, presented as Bray-Curtis resemblance matrices. As an output, this method, which uses the Spearman rank correlation test, reveals a subset of environmental variables that are highly correlated with the biota resemblance matrix.

To identify the pattern of community response to environmental variables, a total of 34 metrics along the investigated stretch of the Danube were analysed using the ASTERICS Software Package, ver. 3.3.1 (AQEM Consortium, 2002) as follows: the species richness and abundance of 15 different taxa groups (as metrics that describe the benthic assemblages in a simplified way) were estimated as descriptors that generally define the communities along the longitudinal gradient of the river, the data on the total taxa richness (the number of species per sample, the number of families and the number of genera) and the community density (the relative abundance expressed as the number of individuals in the sample). For further analyses, preselection from these 34 metrics was performed. The relative abundance per sample, the total number of species, the total number of families and the total number of genera (4 metrics) were a priori selected as parameters proven to respond in predictable ways to various types and intensities of impacts (Rosenberg and Resh, 1993). Out of the remaining 30 metrics (richness and abundance of taxa groups), preselection was done based on their diversity, occurrence along the river and presence in the majority of Danube sections Spearman's rank correlation coefficient ( $\mathrm{SC}$, for $\mathrm{P}<0.05$ ) was used to identify the relations between these metrics and the environmental variables (chemical water compounds).

\section{RESULTS}

A total of 282 macroinvertebrate taxa were identified (Fig. 2). Aquatic insects were found to be dominant in the macroinvertebrate communities along the whole Danube stretch. Chironomidae (Diptera) was the most diverse family with 86 identified taxa, followed by other insect orders, Trichoptera (25 taxa) and Ephemeroptera (13 taxa). Apart from insects, other groups such as Oligochaeta (40 taxa), Crustacea (24 taxa), Bivalvia (23 taxa) and Gastropoda (21 taxa), were also characterized by high taxa richness. Regarding the number of taxa per sampling site, the lowest number (13 taxa) was recorded at site JDS32 (upstream from Novi Sad, Serbia), while the highest number of taxa (63) was at site JDS14 (the Gabčikovo reservoir, Slovak Republic) (Fig. 1).

Based on the FS procedure, 7 out of the 20 analysed RBS pollutants were found to be significantly correlated (assessed by the Monte Carlo test for $\mathrm{P}<0.05$ ) with macroinvertebrate communities along the Danube River

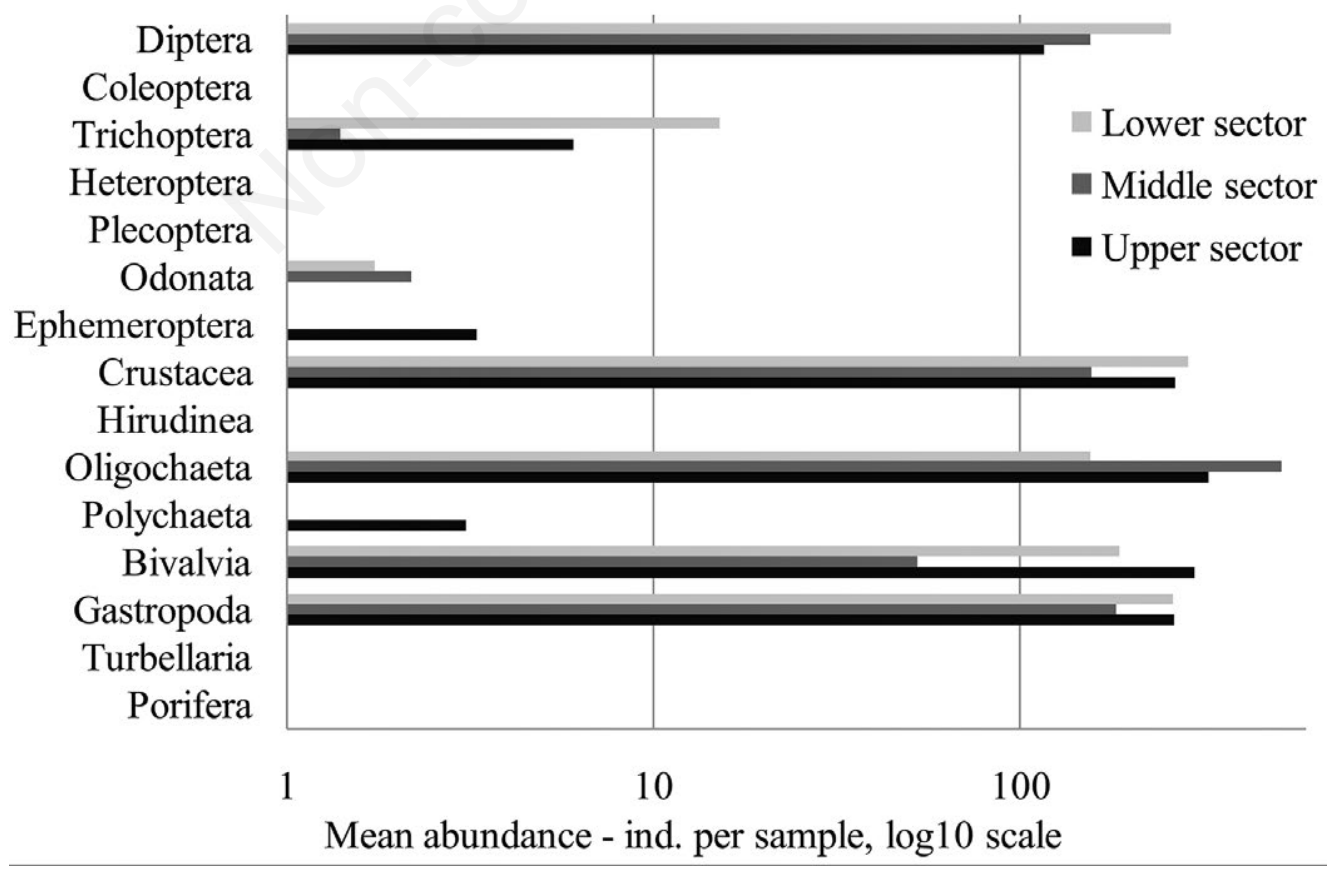

Fig. 2. The mean abundance of macroinvertebrates along the Danube River. 
(Tab. 2), based on the analyses of the data on the relative abundance of species (density per sample) and measured concentrations of chemical compounds per site. Since the highest score on the $\mathrm{x}$-axis of DCA was notably higher than 4.SD, which indicated high heterogeneity of the macroinvertebrate community, CCA was applied. The CCA results of the relative abundance of species at sites and selected RBS pollutants are shown in Fig. 3. The first and second axes explain $54 \%$ of the total variance. The Monte Carlo permutation tests revealed significant species-selected RBS pollutant correlations for the first two axes $(\mathrm{P}<0.05)$. In the middle stretch of the Danube (S4 and S5), benthic communities were clearly determined by two variables that represent the pollution originating from chloroxuron and bromacil (i.e. herbicides), and by one variable that underlines the influence of amoxicillin (i.e. antibiotics).

The following taxa showed positive correlation with the mentioned pollutants, especially with bromacil: Bivalvia (Pisidium supinum Schmidt, 1851, $P$. henslowanum Sheppard, 1823, P. nitidum Jenyns, 1832, P. casertanum Poli, 1791, P. moitessierianum Paladilhe, 1866, P. subtruncatum Malm, 1855), Gastropoda (Theodoxus fluviatilis Linnaeus, 1758, Viviparus viviparus Linnaeus, 1758), Oligochaeta (Nais barbata Müller, 1773, N. elinguis Müller, 1774). Benthic communities in the lower stretch of the Danube were exposed to high concentrations of 2,4-dinitrophenol (DNP) (a chemical with multiple uses in pesticides, dyes and wood preservatives, and in a weight-loss drug),

Tab. 2. The results of the Forward Selection method (Monte Carlo Permutation Test for $\mathrm{P}<0.05$ ), the relative abundance of species at sites (individuals per K\&S sample) and selected RBS pollutants $(\mu \mathrm{g} / \mathrm{L})$.

\begin{tabular}{llccc} 
RBS pollutant & Substance type & Variable & Eigenvalue & Probability (P) \\
Chloroxuron & Herbicide & Chlx & 0.2345 & 0 \\
\hline Bentazon & Herbicide & BENT & 0.2339 & 0.014 \\
\hline 2,4-Dinitrophenol & Multiple use & DNP & 0.2011 & 0.028 \\
\hline Dimefuron & Herbicide & Dime & 0.1781 & 0.01 \\
\hline Amoxicillin & Antibiotic & AMOX & 0.1777 & 0.016 \\
\hline Bromacil & Herbicide & Brcil & 0.1613 & 0.018 \\
\hline Fluoranthene & PAH & FLAN & 0.144 & 0.046
\end{tabular}
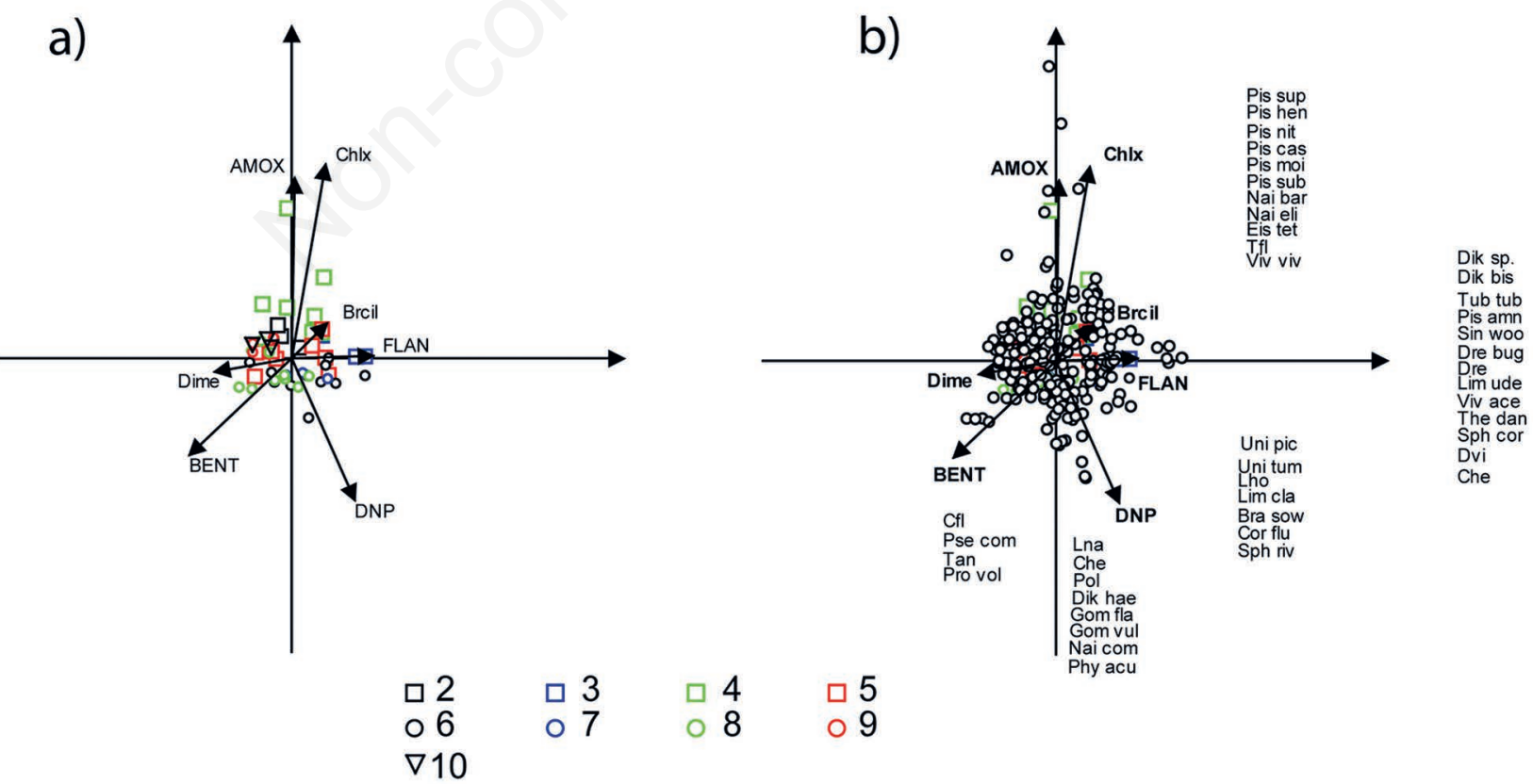

Fig. 3. CCA plot with the singular value decomposition (SVD) algorithm in relation to macroinvertebrates and selected RBS pollutants (variables) along the Danube River (Monte Carlo test, $\mathrm{P}<0.05$ ). a) Plot of sites and variables. b) Bi-plot (sites and species) and variables. Numbers 2-10 identify the sectors according to Danube Typology (Robert et al., 2003; Sommerwerk and Hein, 2009). 
bentazon, dimefuron, (herbicides) and fluoranthene (a polycyclic aromatic hydrocarbon or $\mathrm{PAH}$ ). Bivalvia (Corbicula fluminea Müller, 1774, Pseudanodonta complanata Rossmässler, 1835), Chironomidae (Tanytarsus spp.), Oligochaeta (Propappus volki Michaelsen, 1916) stood out as taxa that were positively correlated with bentazon.

Based on the analysed datasets, we found that the following species were positively correlated with DNP in water: Gastropoda (Lithoglyphus naticoides Pfeiffer, 1828, Physella acuta Draparnaud, 1805), Crustacea (Chelicorophium curvispinum Sars, 1895, Dikerogammarus haemobaphes Eichwald, 1841), Oligochaeta (N. communis Piguet, 1906), Chironomidae (Polypedilum (Tripodura) scalaenum Schrank, 1803), Odonata (Gomphus flavipes Charpentier, 1825, G. vulgatissimus Linnaeus, 1758).

On the other hand, analyses revealed that some of the recorded taxa were positively correlated with fluoranthene in water; these included Bivalvia (Dreissena sp., D. bugensis Andrusov, 1897, Sinanodonta woodiana Lea, 1834, P. amnicum Müller, 1774, Sphaerium corneum Linnaeus, 1758), Gastropoda (T. danubialis Pfeiffer, 1828, $V$ acerosus Bourguignat, 1862), Crustacea (Dikerogammarus sp., D. bispinosus Martynov, 1925, D. villosus Sowinski, 1894, Chelicorophium sp.), Oligochaeta (Tubifex tubifex Müller, 1774, Limnodrilus udekemianus Claparede, 1862). Some taxa displayed positive correlation to both DNP and fluoranthene: Bivalvia (Unio pictorum Linnaeus, 1758, U. tumidus Philipsson, 1788, Corbicula fluminalis Müller, 1774, S. rivicola Lamarck, 1818), Oligochaeta (L. hoffmeisteri Claparede, 1862, L. claparedeanus Ratzel, 1868, Branchiura sowerbyi Beddard, 1892).

The BIO-ENV derived three RBS pollutant combinations that significantly $(p=0.01)$ determine community structure (Tab. 3). The first model provided the combination of 5 RBS pollutants (DNP, chloroxuron, diazinon, bentazon, benzo(a)pyrene), which significantly correlated (Spearman's rank correlation coefficient, $\mathrm{Rho}=0.289 ; \mathrm{P}=0.01$ ) with the spatial variability of the macroinvertebrate community. The results of BIO-ENV indicate that these three combinations of pollutants exhibit synergistic effect on the communities.

We also studied the relation of the biological metrics and parameters that were found to be relevant for the investigated river, based on previously described procedures. The aim was to choose effective indicators, which could be used for screening for the presence of substances identified as the most important for the Danube River. The use of biological traits could reduce the efforts needed for the assessment, since in some cases for their calculation there is no need for identification to the species level (e.g. abundance-related metrics and taxa richness expressed as the total number of genera, or families).

Thus, out of the 34 calculated biological metrics, 18 were used for supplementary analyses. The relative abundance per sample, the total number of species, the total number of families and the total number of genera, as well as the richness and abundance of insect orders, Diptera, Odonata and Trichoptera, Oligochaeta, Gastropoda, Bivalvia and Crustacea were chosen (Tab. 4).

A total of 360 relations (matrix: 18 selected matrices x 20 analysed RBS pollutants) were analysed by SC. For 89 iterations, the rank order correlation was found to be significant $(\mathrm{P}<0.05)$, with 29 iterations with a negative, and 60 iterations with a positive correlation of pairs. The variables found not significant by the FS were excluded, and finally 12 relations were selected (five pollutants and 12 biological metrics) (Tab. 5). Thus, based on a step-bystep elimination, the linkages between metric and RBS pollutants were identified.

\section{DISCUSSION}

Having in mind that huge amounts of different chemicals are released into the environment, and that there are time and budget limitations for their assessment, there is an obvious need to single out chemicals that are essential for monitoring (von der Ohe et al., 2011). It is also, necessary to develop more effective biomonitoring tools. The present study was performed in order to identify which chemicals (RBS pollutants) have the highest correlation with macroinvertebrate assemblages in the Danube River. The interactions of macroinvertebrate communities and river-specific pollutants (contaminants that were found to be important for the Danube River Basin according to Slobodnik and

Tab. 3. BIO-ENV analysis reveals the first three best RBS pollutant combinations for the macroinvertebrate community data matrix with values of Spearman's rank correlations (Rho) and P.

\begin{tabular}{llll} 
& P & Rho & Best RBS pollutants combination \\
\hline 1 & 0.01 & 0.289 & 2,4-dinitrophenol (DNP), chloroxuron, diazinone, bentazon, benzo(a)pyrene \\
\hline 2 & 0.01 & 0.280 & Chloroxuron, diazinone, bentazon, benzo(a)pyrene \\
\hline 3 & 0.01 & 0.280 & Chloroxuron, diazinone, bentazon, benzo(a)pyrene, 2-hydroxy atrazine
\end{tabular}


von der Ohe, 2015) were analysed. Our aim was to identify noteworthy relations in order to validate the selection of RBS pollutants identified as important based on the MEC95/PNEC ratio (Slobodnik and von der Ohe, 2015), as well as to identify macroinvertebrates that could be further used in evaluation as effective indicators for particular pollutants or group of pollutants.

Using different analyses, this study confirmed that patterns of macroinvertebrate communities can be used as a tool for the prioritization of environmental variables in terms of their relationship with xenobiotics. A better understanding of the interactions between different pollutants and macroinvertebrate communities will improve our ability to predict how communities respond and recover from the effects of xenobiotics and whether they can serve as a tool for assessing the effectiveness of remediation measures.

Based on the obtained results, a variety of taxa, such as species belonging to Oligochaeta (Annelida), Chironomidae (Insecta: Diptera) and Mollusca, were

Tab. 4. Selected metrics along the Danube River, expressed as the average, maximum and minimum values, and the standard deviation (St. dev).

\begin{tabular}{|c|c|c|c|c|c|}
\hline Metrics & Abbreviations & Average & $\operatorname{Max}$ & Min & St. dev \\
\hline Total abundance & $\mathrm{Abu}$ & 1394.11 & 6381 & 18 & 1574.97 \\
\hline Total no. of taxa & NT & 24.60 & 50 & 2 & 10.95 \\
\hline Total no. of families & $\mathrm{NoF}$ & 11.29 & 23 & 1 & 4.50 \\
\hline Total no. of genera & NoG & 20.11 & 42 & 2 & 8.78 \\
\hline No. of taxa - Diptera & DipT & 7.54 & 21 & 0 & 5.65 \\
\hline No. of taxa - Odonata & OdT & 0.36 & 2 & 0 & 0.62 \\
\hline No. of taxa - Trichoptera & TriT & 0.85 & 5 & 0 & 1.36 \\
\hline No. of taxa - Oligochaeta & OliT & 3.91 & 8 & 0 & 2.24 \\
\hline No. of taxa - Gastropoda & GasT & 2.33 & 6 & 0 & 1.83 \\
\hline No. of taxa - Bivalvia & BivT & 3.28 & 11 & 0 & 2.56 \\
\hline No. of taxa - Crustacea & CruT & 5.56 & 11 & 0 & 2.79 \\
\hline Total abundance - Diptera & Dip_Ab & 203.07 & 4019 & 0 & 614.12 \\
\hline Total abundance - Odonata & Odo_Ab & 1.86 & 57 & 0 & 8.74 \\
\hline Total abundance - Trichoptera & Tri_Ab & 12.62 & 877 & 0 & 120.50 \\
\hline Total abundance - Oligochaeta & Oli_Abund & 355.56 & 4165 & 0 & 798.45 \\
\hline Total abundance - Gastropoda & Gastr_Abund & 266.95 & 3120 & 0 & 577.23 \\
\hline Total abundance - Bivalvia & Biv_Abund & 260.82 & 2324 & 0 & 529.79 \\
\hline Total abundance - Crustacea & Crus_Abund & 289.57 & 4704 & 0 & 720.21 \\
\hline
\end{tabular}

Tab. 5. Results of relations between metrics and selected pollutants after step-by-step elimination. Abbreviations for selected metrics were given in Tab. 4.

\begin{tabular}{llll} 
& Spearman & t(N-2) & P-level \\
TriT \& Bentazon & -0.382971 & -414.578 & 0.000071 \\
\hline Tri_Ab \& Bentazon & -0.371013 & -399.528 & 0.000124 \\
\hline DipT \& Bentazon & -0.257950 & -266.985 & 0.008857 \\
\hline Dip_Ab \& Bentazon & -0.205747 & -210.245 & 0.038025 \\
\hline NT \& Bentazon & -0.196637 & -200.553 & 0.047608 \\
\hline OliT \& Dimefuron & -0.229551 & -235.849 & 0.020294 \\
\hline CrusAbund \& Dimefuron & -0.211300 & -216.181 & 0.033019 \\
\hline OliAbund \& Dimefuron & -0.198227 & -202.240 & 0.045805 \\
\hline CruT \& 2,4-Dinitrophenol & -0.246140 & -253.953 & 0.012640 \\
\hline Gastr_Abund \& Fluoranten & -0.197674 & -201.653 & 0.046426 \\
\hline Odo_Ab \& Chloroxuron & -0.373276 & -402.359 & 0.000112 \\
\hline OdT \& Chloroxuron & -0.309885 & -325.929 & 0.001527 \\
\hline
\end{tabular}


present in occurrences of different pollutants. The presence of organic compounds in aquatic ecosystems could cause changes in community structure (Schäfer et al., 2007). Likewise, the macroinvertebrate communities found in the eastern and lower Alpine foothills, as well as along the Hungarian stretch of the Danube, were characterized by the predominance of insects (mostly Diptera: Chironomidae) and aquatic worms (Annelida: Oligochaeta). These sites were exposed to increased concentrations of the pesticides (herbicides), bentazon, chloroxuron, bromacil and dimefuron. Pesticides have many possible sources and are generally considered as pollutants that possess the potential to decrease the relative abundance as well as number of sensitive taxa in macroinvertebrate communities (Schäfer et al., 2007). Pesticides can affect all groups of aquatic organisms, such as microorganisms (DeLorenzo et al., 2001; Schäfer et al., 2007), macroinvertebrates (Castillo et al., 2006; Kuzmanović et al. 2016; Maund et al., 1997), plants (Suresh Kumar and Han, 2011) and fish (Grande et al., 1994; Slaninová et al., 2009; Eqani et al., 2013).

Using the relation between macroinvertebrate assemblages and RBS pollutants in the Danube, this study confirmed the importance of herbicides and DNP, as well as the importance of the antibiotic amoxicillin and the PAH fluoranthene. Among the dinitrophenol class of compounds, DNP is a widely used synthetic chemical as a component of agricultural pesticides, wood preservers, dyes, explosives and a weight-loss agent (Miranda et al., 2006). The entire ecosystems and aquatic organisms could be disrupted by those commercially available herbicides.

The high abundance of Chironomidae and Oligochaeta species is typical for the entire navigable stretch (lower stretches) of the Danube River (Literáthy et al., 2002; Csányi and Paunović, 2006; Graf et al., 2015a, 2015b). This distribution suggests that chironomids and oligochaetes are more tolerant to organic compounds in comparison to other macroinvertebrate groups. The tolerance of oligochaetes has been extensively discussed in many studies and this group is generally used to describe the human impact on the environment (Rodriguez and Reynoldson, 2011). Numerous data demonstrate the sensitivity of oligochaetes to pesticides, PAHs and other compounds, as well as their capability to repair communities by increasing the number of taxa and abundance faster than the other macroinvertebrate groups (Rodriguez and Reynoldson, 2011). It was reported that herbicides reduced the food supply for benthic grazers as they inhibit the growth of aufwuchs; moreover, they can lead to starvation, followed by reduction of growth, energy storage, slowing down population development (Rybicki et al., 2012).
Even though FS and CCA revealed the connection between species and analysed xenobiotics, in many cases this relation did not provide a logical frame for using certain species as reliable indicators. The reason for this is the cooperative (combined and/or synergistic) influence of many environmental variables, including both natural and the anthropogenic factors, multiple stressors, as well as their characteristic distribution within the space. Another reason is related to the distribution of the macroinvertebrate assemblages, as many species occur rarely, with a low abundance, due to the combined influence of many environmental variables, including multiple stressors. In order to minimize the influence of the longitudinal river gradient on the results, only taxa that were widely distributed along the entire analysed river stretch were taken into the consideration. Thus, Ephemeroptera were excluded from the analyses, since this insect order is only characteristic for the upper stretch of the Danube River.

Our results indicate that the number of Diptera and Trichoptera taxa and their abundance decreased significantly with increasing levels of bentazon in the environment. Likewise, Akerblom (2004) noted that the survival rates and abundance of some species of Trichoptera decreased with increasing concentrations of pesticides. On the other hand, insects belonging to the Chironomidae (Diptera) family appeared to respond differently to pesticides. Wallace et al. (1989) and Friberg et al. (2003) found that in the presence of pesticides the number of Chironomidae increased, while in contrast, Dieter et al. (1996) showed that pesticides caused a decrease in their abundance, which is in correlation with our results.

The increase in dimefuron concentration led to a reduction in the abundance and diversity of Oligochaeta and the abundance of Crustacea. This relation between Crustacea and the pesticide is in accordance with previous findings (Dieter et al., 1996; Liess and Schulz, 1999; Friberg et al., 2003).

In the context of certain herbicides (bromacil) and antibiotics (amoxicillin) and their correlation with selected metrics, Spearman correlation analyses showed a strong positive correlation between these two datasets. Even though our results suggest that there were some correlations between antibiotics (amoxicillin) and macroinvertebrates, there is still insufficient information regarding this subject, especially in natural habitats, and thus it is hard to make a conclusion. Some studies on the pharmaceutical effects on invertebrates (e.g. Hydra vulgaris, Gammarus pulex) have been undertaken (Watts et al., 2001; Pascoe et al., 2003). Further investigations into the potential toxicity of pharmaceuticals on freshwater macroinvertebrates are needed.

In general, our study confirms that statistically 
significant correlations exist between the pollutants preselected by the NORMAN procedure as RBS pollutants for the Danube River and macroinvertebrates. However, the relation between macroinvertebrate communities and pressures in an aquatic environment is more complex. Rico et al. (2016) reported that chemical pollution in isolation has a relatively low contribution to macroinvertebrate communities in comparison with habitat characteristics and physicochemical conditions, especially in the case of large rivers. The actual impact of different chemical compounds on aquatic biota remains to be elucidated, particularly in a multi-stressor environment (Navarro-Ortega et al., 2015), which is often the situation in the case of water bodies situated in densely-populated areas.

\section{CONCLUSIONS}

Our results indicate that combinations of the examined RBS pollutants express synergistic effect on communities. Out of 20 preselected Danube RBS, chloroxuron, bentazon, DNP, dimefuron, amoxicillin, bromacil and fluoranthene have the highest correlation with macroinvertebrate communities. At sites exposed to increased concentrations of pesticides, insects (mostly Chironomidae), aquatic worms (Oligochaeta) and Mollusca were increased in abundance and number of taxa, while the number of sensitive taxa was decreased.

Additionally, the BIO-ENV model confirmed that the combination of 5 RBS pollutants (DNP, chloroxuron, diazinon, bentazon, benzo(a)pyrene) is the most important variable structuring faunal communities in the Danube River. We are aware that the relationship between community and chemical stressors in an aquatic environment is complex and that this study can only provide an indication of the relation. It is necessary to combine several indicators to increase confidence in the bioassessment at the community level, which would be usable in water management. It is also important to combine field and laboratory experiments in order to identify the complex relations of stressors and the environment. Optimization of such an approach is extremely important, since the production of new potential stressors from the industrial sector (newly emerging substances) is enormous (Navarro-Ortega et al., 2015).

This study is an important step in the biological valorisation of RBS pollutants that were previously recognized as key stressors according to the MEC95/PNEC ratio (Slobodnik and von der Ohe, 2015). Our work provides additional evidence in supporting the procedure of RBS pollutants selection and thus contributes to a more effective management of chemical compounds.

\section{ACKNOWLEDGMENTS}

The material for this study was collected as a part of the Joint Danube Survey 3 expedition. The research was realized in August and September 2013 under the coordination of the International Commission for the Protection of the Danube River (ICPDR) and with the financial contribution of the "Danubian" countries and the European Commission.

We would like to express our gratitude to all participants in the JDS3 expedition, with a special acknowledgement for the assistance of the Secretariat General of the ICPDR for its support during the investigation.

The preparation of the manuscript was supported by the Ministry of Education, Science and Technological Development of the Republic of Serbia, Grant Nos. 176018 and 173025 . We also express our appreciation to Dr Goran Poznanović from the Institute for Biological Research "Siniša Stanković", University of Belgrade, for his help in the development of the approach presented herein and suggestions for improving the structure of the manuscript.

\section{REFERENCES}

Akerblom N, 2004. Agricultural pesticide toxicity to aquatic organisms - a literature review. Dep. Environ. Assess. Swedish Univ. Agric. Sci 16:1-31.

AQEM Consortium, 2002. Manual for the application of the Aqem system: A comprehenssive method to assess European streams using benthic macroinvertebrates, developed for the purpose of the Water Framework. University Duisburg-Essen, Germany, Essen, 198 pp.

Castillo LE, Martínez E, Ruepert C, Savage C, Gilek M, Pinnock M, Solis E, 2006. Water quality and macroinvertebrate community response following pesticide applications in a banana plantation, Limon, Costa Rica. Sci. Total Environ 367:418-432.

Clarke KR., Warwick RM, 2001. Changes in marine communities: an approach to statistical analysis and interpretation, PRIMER-E.

Collier K, Clapcott J, David B, Death R, Kelly D, Leathwick J, Young R, 2013. Macroinvertebrate-pressure relationships in boatable New Zealand Rivers: Influence of underlying environment and sampling substrate. River Res. Applic 29:645-659. doi: 10.1002/rra.2564.

Csányi B, Paunović M, 2006. The aquatic macroinvertebrate community of the River Danube between Klostenburg (1942 rkm) and Calafat - Vidin (795 rkm). Acta Biol. Debrecina Suppl. Oecologica Hungarica 14:91-106.

DeLorenzo ME, Scott GI, Ross PE, 2001. Toxicity of pesticides to aquatic microorganisms: a review. Environ. Toxicol. Chem 20:84-98.

Dieter CD, Duffy WG, Flake LD, 1996. The effect of phorate on wetland macroinvertebrates. Environ. Toxicol. Chem 
15:308-312.

Eqani SA, Malik RN, Cincinelli A, Zhang G, Mohammad A, Qadir A, Rashid A, Bokhari H, Jones KC, Katsoyiannis A, 2013. Uptake of organochlorine pesticides (OCPs) and polychlorinated biphenyls (PCBs) by river water fish: The case of River Chenab. Sci. Total Environ 451:83-91.

European Union, 2013. Directive 2013/39/EU of the European Parliament and of the Council of 12 August 2013 amending Directives 2000/60/EC and 2008/105/EC as regards priority substances in the field of water policy. European Parliament, European Union Council, 226 pp.

Friberg N, Lindstrøm M, Kronvang B, Larsen SE, 2003. Macroinvertebrate/sediment relationships along a pesticide gradient in Danish streams. Hydrobiologia 494:103-110.

Graf W, Csányi B, Leitner P, Paunović M, Huber T, Szekeres J, Nagy C, Borza P, 2015a. Macroinvertebrates, p. 81-99. In: I. Liška, F. Wagner, M. Sengl, K. Deutch, and J. Slobodnik (eds.), Joint Danube Survey 3. A comprehensive analysis of Danube water quality. International Commission for the Protection of the Danube River, Vienna.

Graf W, Leitner P, Pletterbauer F, 2015b. Short Overview on the Benthic Macroinvertebrate Fauna of the Danube River. Handb. Environ. Chem 39:287-316.

Grande M, Andersen S, Berge D, 1994. Effects of pesticides on fish. Experimental and field studies. Nor. J. Agric Sci. Suppl.13:195-209.

Karadžić B, 2013. FLORA: A software package for statistical analysis of ecological data. Water Res. Manag. 3:45-54.

Kolarevic S, Knezevic-Vukcevic J, Paunovic M, Tomovic J, Gacic Z, Vukovic-Gacic B, 2011. The anthropogenic impact on water quality of the River Danube in Serbia: Microbiological analysis and genotoxicity monitoring. Arch. Biol. Sci 63:1209-1217.

Kuzmanović M, López-Doval CJ, De Castro-Català N, Guasch H, Petrović M, Muñoz I, Ginebreda A, Barceló D, 2016. Ecotoxicological risk assessment of chemical pollution in four Iberian river basins and its relationship with the aquatic macroinvertebrate community status. Sci. Total Environ 540:324-333.

Liess M, Schulz R, 1999. Linking insecticide contamination and population response in an agricultural stream. Environ. Toxicol. Chem 18:1948-1955.

Liška I, Wagner F, Sengl M, Deutch K, Slobodnik J, 2015. Joint Danube Survey 3. A comprehensive analysis of Danube water quality. International Commission for the Protection of the Danube River, Vienna: 369 pp.

Liška I, Wagner F, Slobodnik J, 2008. Joint Danube Survey 2. Final Scientific Report. International Commission for the Protection of the Danube River, Vienna: $242 \mathrm{pp}$.

Literáthy P, Koller-Kreimel V, Liska I, 2002. Joint Danube Survey Technical Report. International Commission for the Protection of the Danube River, Vienna: $30 \mathrm{pp}$.

Maund S, Barber I, Dulka J, Gonzalez-Valero J, Hamer M, Heimbach F, Marshall M, McCahon P, Staudenmaier H, Wustner D, 1997. Development and evaluation of triggers for sediment toxicity testing of pesticides with benthic macroinvertebrates. Environ. Toxicol. Chem 16:2590-2596.

Melo AS, 2009. Explaining dissimilarities in macroinvertebrate assemblages among stream sites using environmental variables. Zool. (Curitiba, Impr.) 26:79-84.
Milošević D, Čerba D, Szekeres J, Csányi B, Tubić B, Simić V, Paunović M, 2016. Artificial neural networks as an indicator search engine: The visualization of natural and man-caused taxa variability. Ecol. Indic 61:777-789.

Miranda EJ, McIntyre IM, Parker DR, Gary RD, Logan BK, 2006. Two deaths attributed to the use of 2,4-dinitrophenol. J. Anal. Toxicol 30:219-222.

Navarro-Ortega A, Acuña V, Bellin A, Burek P, Cassiani G, Choukr-Allah R, Dolédec S, Elosegi A, Ferrari F, Ginebreda A, Grathwohl P, Jones C, Rault PK, Kok K, Koundouri P, Ludwig RP, Merz R, Milacic R, Muñoz I, Nikulin G, Paniconi C, Paunović M, Petrovic M, Sabater L, Sabaterb S, Skoulikidis NT, Slob A, Teutsch G, Voulvoulis N, Barceló D, 2015. Managing the effects of multiple stressors on aquatic ecosystems under water scarcity. The GLOBAQUA project. Sci. Total Environ 503-504: 3-9.

Pascoe D, Karntanut W, Müller CT, 2003. Do pharmaceuticals affect freshwater invertebrates? A study with the cnidarian Hydra vulgaris. Chemosphere 51:521-528.

Rico A, Van den Brink PJ, Leitner P, Graf W, Focks A, 2016. Relative influence of chemical and non-chemical stressors on invertebrate communities: a case study in the Danube River. Sci. Total Environ. 571:1370-1382.

Robert S, Sommerhäuser M, Birk S, 2003. Typology of the Danube River - part 1: top-down approach. UNDP/GEF Danube Regional Project, University of Duisburg-Essen, Essen, Germany and BOKU - University of Natural Resources and Applied Life Sciences A-1180 Vienna, Austria.

Rodriguez P, Reynoldson T, 2011. The pollution biology of aquatic oligochaetes. Springer, Dordrecht: 265 pp.

Rosenberg D, Resh VH, 1993. Freshwater biomonitoring and benthic macroinvertebrates. Chapman \& Hall, New York: 488 pp.

Rybicki M, Winkelmann C, Hellmann C, Bartels P, Jungmann D, 2012. Herbicide indirectly reduces physiological condition of a benthic grazer. Aquat. Biol .17:153-166.

Schäfer RB, Caquet T, Siimes K, Mueller R, Lagadic L, Liess $\mathrm{M}, 2007$. Effects of pesticides on community structure and ecosystem functions in agricultural streams of three biogeographical regions in Europe. Sci. Total Environ. 382:272-285.

Slaninová A, Smutna M, Modra H, Svobodova Z, 2009. A review: Oxidative stress in fish induced by pesticides. Neuroendocrinol. Lett 30:2-12.

Slobodnik J, Ipolyi I, Derksen A, Kühne R, Ost N, von der Ohe PC, 2015. Prioritisation and identification of Danube River basin specific pollutants, p. 342-348. In: I. Liška, F. Wagner, M. Sengl, K. Deutch and J. Slobodnik, (eds.), Joint Danube Survey: A comprehensive analyses of Danube water quality. International Commission for the Protection of the Danube River, Vienna.

Slobodnik J, von der Ohe PC, 2015. Identification of the Danube River basin specific pollutants and their retrospective risk assessment. In: I. Liška, (ed.), The Danube River Basin. Springer-Verlag, Berlin Heildeberg, 95-110.

Sommerwerk N, Hein T, Schneider-Jakoby M, Baumgartner C, Ostojić A, Paunović M, Bloesch J, Siber R, Tockner K, 2009. The Danube River Basin, p. 59-112. In: K. Tockner, U. Uehlinger and C. T. Robinson (eds.), Rivers of Europe. Academic Press, London. 
Sommerwerk N, Bloesch J, Paunovic M, Baumgartner C, Venohr M, Schneider-Jacoby M, Hein T, Tockner K, 2010. Managing the world's most international river: the Danube River Basin. Mar. Freshw. Res 61:736-748.

Suresh Kumar K, Han T, 2011. Toxicity of single and combined herbicides on PSII maximum efficiency of an aquatic higher plant, Lemna sp. Toxicol. Environ. Health Sci. 3:97-105. von der Ohe PC, Dulio V, Slobodnik J, De Deckere E, Kühne R, Ebert RU, Ginebreda A, De Cooman W, Schüürmann G, Brack W, 2011. A new risk assessment approach for the prioritization of 500 classical and emerging organic microcontaminants as potential river basin specific pollutants under the European Water Framework Directive. Sci. Total Environ. 409:2064-2077.

Wallace JB, Lugthart GJ, Cuffney TF, Schurr GA, 1989. The impact of repeated insecticidal treatments on drift and benthos of a headwater stream. Hydrobiologia 179:135-147.

Watts MM, Pascoe D, Carroll K, 2001. Survival and precopulatory behaviour of Gammarus pulex (L.) exposed to two xenoestrogens. Water Res. 35:2347-2352.

Weatherhead MA, James MR, 2001. Distribution of macroinvertebrates in relation to physical and biological variables in the littoral zone of nine New Zealand lakes. Hydrobiologia 462:115-129. 